\title{
New Initiatives In State Economic Development Promotion: New England Prototypes\#
}

\author{
Martin T. Katziman*

\section{INTRODUCTION}

State economic development incentives tend to have two major characteristics. First, financing incentives concentrate on an extremely narrow band in the spectrum of business requirements, i.e., in the financing of plant and equipment. Second, promotional programs are zero-sum in spirit if not in practice, i.e., their avowed purpose is attracting industry from elsewhere. Largely because of these rhetorical purposes, economists generally view state economic development promotion as the height of Babbittry, with a heavy dose of special pleading for largess from the federal porkbarrel, and consequently of no aggregate benefit. In this context some recent innovations in economic development finance emerging from New England are of considerable national interest: they operate in new areas of finance, at least for states, and unlike zero-sum instruments such as tax incentives, they would be beneficial if diffused nationally.

That New England is a great incubator of state development finance institutions may come as a surprise. It is certainly surprising to New Englanders who view the South as the most innovative and aggressive region in creating development programs to attract industry, particularly from New England. In fact, the opposite is true [Katzman and Daniels, 1975]. New England continues to be not only an incubator of hightechnology manufactures, but also of financial innovations. Private sector innovations include the credit union, the trust company, the mutual fund, the venture capital company, and the NOW account. Of special interest here, public sector innovations of the 1950's included the development credit corporation, mortgage-loan guarantees, industrial land banking, and statewide speculative building. All of these public mechanisms are characterized by the pooling of risks and reducing of transactions costs, and hence market perfecting. In contrast, the most prominent financial incentive offered by southern states has been the industrial

\#Presented at the Southern Regional Science Association meetings in Richmond, April 9, 1976. This analysis was initiated under a contract from the New England Regional Commission and completed under a small grant from the First National Bank of Boston. The author is indebted to Peter Fortune, Pat Choate, and Sharon Oster for advice and comments; and to McKim N. Barnes, Judith Payne, Bruce Ai, and Michael Bier for assembling the data.

* Professor and Head, Program in Political Economy, University of Texas at Dallas. 
revenue bond, which essentially provides a federal subsidy to private industry at the initiative of the state, which bears absolutely no risk.

In this paper, three New England innovations of the 1970's are analyzed: the municipal bond bank, the umbrella revenue bond, and the product development corporation. The first has been in operation in Vermont since 1970 and in Maine since 1972. To our knowledge, Puerto Rico is the only jurisdiction outside of New England to have adopted this institution. Umbrella revenue bonding has been in operation in a rudimentary form in Connecticut since 1973. Operating on the basis of bond anticipation notes prior to this, the umbrella program issued its first long-term bond in December 1975. Finally, a product development corporation has been in operation, also in Connecticut, since May 1975.

\section{MUNICIPAL BOND BANKING}

Infrastructure is commonly viewed as a "prerequisite" for economic development in relatively backward regions. Based upon this perception, the Economic Development Administration has devoted the major share of its grants and loans to the construction of transportation facilities, sewerage, and other public works. While many development economists have come to denigrate the notion of "prerequisites" [e.g., Hirschman, 1958], particularly in the American context, there is increasing evidence that the availability of airports, highways, and sewerage plays a major role in, at least, micro-regional location decisions [Gishlick, 1974]. With the rise of environmental protection legislation, the cost of sewerage treatment is bound to become more important in locational decisions. To the extent that industries are becoming increasingly footloose and costs are becoming more uniform, amenities such as public recreational facilities and other aspects of environmental quality may increasingly become a differential factor that attracts managerial and technical talent to the community's industry.

The implications of this "new prerequisites" argument are that to the extent certain communities, by virtue of their size or location, are disadvantaged in their access to the municipal general obligation bond market, then their ability to provide infrastructure and hence to attract or generate industry will be reduced.

This problem is allegedly most acute for small, often unrated municipalities which make infrequent appearance in public capital markets. Such municipalities may have to pay differentially high interest rates that do not reflect their actuarial risk of default. Because there are large fixed costs of floating debt issues publicly, issuers of small credits have to pay an especially high transactions cost as a share of the face value of the issue. A method of circumventing these difficulties is the private placement of municipal debt in local banks, which have greater information about, and greater stake in, these communities. While such placements avoid the transactions costs and excessive risk premiums, they place the municipality at the mercy of a single bidder for their securities. 
The imperfections in this segment of the capital market are indicated by the fact that nearly one-half of all municipal infrastructure is financed out of current revenues rather than by borrowing. This is similar to placing a 50 percent down-payment on a home. Of the 50 percent of infrastructure financed by debt, fully two-fifths is placed privately [Goldsmith, 1968].

\section{The Operation of a Municipal Bond Bank}

Simply stated, a municipal bond bank underwrites or purchases the general obligations of its taxing subdivisions, such as towns or school districts. The bank in turn sells a consolidated bond, with a term structure and aggregate value equivalent to the component bonds, plus approximately ten percent for a reserve fund. The security behind the bank bonds are first the reserve fund which is sufficient to cover a year's debt service, then the full faith and credit of the towns and districts, and finally a moral obligation of the state to replenish this reserve fund in the case of depletion. The reserve fund is amortized by "balloon payments" as the bonds near maturity. In the interim, reserves are invested in U.S. Treasury obligations. As a result of the spread between yields on these taxable instruments and the state's tax-exempt borrowing rate, a small surplus is earned which can pay the bond bank's operating costs.

To participate in a bond bank issue, the town must first meet its constitutional obligations, such as having an election if necessary, as verified by an opinion from its bond counsel. The town then submits an application to the bond bank providing the type of information normally used by credit rating agencies, such as anticipated tax collections, assessed valuation per capita, overlapping debt per assessed evaluation, percentage of tax delinquencies. If, in the judgment of the bank's financial adviser, a particular town will undermine the overall credit-worthiness of the bond bank issue, the town can be refused participation. While in practice that has never happened, the possible danger of politically motivated exclusion exists.

The bond bank circulates a notice and prospectus, prints the bonds, obtains a rating, floats a consolidated issue through an underwriter, purchases local debt with the proceeds, collects debt service from the municipalities, and transfers these funds to its own paying agent. The costs of these operations are not charged explicitely against the towns, but are recouped by the premium offered by the underwriters.

\section{Financial Impact of the Bond Bank}

The municipal bond bank can reduce the cost of borrowing to towns by means of pooling risks and spreading the fixed transactions cost of issuing bonds. These savings operate through several channels: reoffering yields, underwriting spreads, and other transactions costs. 
The magnitude of these cost savings are estimated for each of the four issues of the Vermont and Maine Municipal Bond Banks. These estimates are arrived at by several simplifying assumptions and can only be suggestive of orders of magnitude.

Both reoffering yields and underwriting spreads depend upon many characteristics of debt issues that are unaltered by bond banking, such as the term structure of the bonds, callability, average market interest rates, outstanding debt of borrowers. Bond banking does alter two crucial aspects of debt issues: their average size and their credit rating. Because of the pooling of debt and the existence of the reserve fund, issues of the Bond Banks have been rated $\mathrm{Aa}$, which is one classification below that of general obligations of the two states. In general, the higher the rating of the debt, the greater the number of bidders and hence the lower the reoffering yields and underwriting spreads [Kessel, 1971].

Reoffering yields. Prior to the establishment of the Bond Banks, only about five percent of the towns in Vermont and nine percent of those in Maine were rated. Empirical studies indicate that unrated issues generally enjoy reoffering yields similar to those of Baa bonds [Petersen, 1974, Table 10]. While a rating could be obtained for a fee, the infrequency with which these towns entered the market, the high fee, and the low likelihood of their receiving ratings above Baa dissuaded many towns from doing so.

One impact of the municipal bond bank has been to raise the effective ratings of participating towns to Aa. In the period 1959-1967, the direct consequence of this rating arbitrage is to lower the 20-year reoffering yields by at least 46 basis points. By attracting more bidders, the reoffering yields on these higher quality issues fall by another 3 basis points, for a total of 49 basis points [Kessel, 1971, Tables 9 and 11*; Petersen, 1971, Table 13].

A quantitatively less important impact of the bond bank operates through an increase in issue size. Because institutional investors prefer to deal with larger issues in order to minimize their own transactions costs, reoffering yields tend to vary inversely with size of issue [Kessel, 1971, Table 9]. For the size of issues the Vermont and Maine Bond Banks have consolidated, the savings were on the order of magnitude of only one or two basis points, on the basis of Kessel's coefficients. There is some evidence that the impact of issue size has become absolutely larger in recent years [Forbes and Renshaw, 1972]; however, we are as yet unable to quantify the impact of these trends.

An empirical estimation of the impact of pooling local issues should ideally take into account the maturity structure of the serial bonds and should compare issues which differ only in size and rating. Because the

*While clearly the most exhaustive study of municipal bonds in print, Kessel's study poses problems of extrapolation for our purposes. Excluded from his sample were issues unreported in the Bond Buyer, the trade publication for underwriters. This excludes issues that are of less than $\$ 1$ million or that are privately placed. These omissions make our extrapolations very conservative with respect to reoffering yield and underwriting spread differentials among issues. 
increase in ratings seems to have the greatest quantitative impact on savings, the impact of the bond bank on reoffering yields is estimated by the observed differential between bonds rated $\mathrm{Aa}$ and those with the rating of the municipality, usually Baa, as reported in Moody's Bond Record, for the weeks the bond bank floated its issues. These Moody's bond averages take no account of the differences in term structure and issue sizes of the differently rated bonds. Moreover, these averages reflect only publicly issued bonds of greater than $\$ 1$ million, while a large number of the participating towns could only place their debt privately at higher reoffering yields. In other words, the estimates of savings in reoffering yields (around 40 basis points for unrated towns) are overly conservative in ignoring the effects of increasing issue size and shifting from private to public placement upon yields. Nevertheless, these estimates are of the same order of magnitude (around 50 basis points) as those found by Forbes and Renshaw [1972], who compared "net interest cost" savings of the Vermont Bond Bank by matching maturity and issue size.

The present value of the interest savings can be approximated by either of two methods. Both methods assume that bonds are liquidated with a constant annual debt service, whether or not issued through the bank. Method One assumes that the municipal demand for capital expenditures is completely inelastic. Therefore, the value of bonds issued through the bank would have been identical to the value issued in the absence of the bank at a higher interest rate, and thus higher annual amortization payment. The additional amortization payments can be capitalized by assuming that these annual payments could have amortized a somewhat larger debt at the lower bond bank rate. To the extent that the interestelasticity of demand for municipal infrastructure is less than zero, this method overestimates the consumer surplus from the interest savings.

Method Two assumes a unitary elasticity of demand for capital expenditures. Therefore, in the absence of a bond bank, amortization payments would have been the same, but the value of the capital financed would have been less. The resulting difference underestimates the capital gain from the interest savings, especially since the elasticity of demand for municipal infrastructure is closer to zero than to unity [Phelps, 1961]. In practice, the two methods produce estimates which differ only on the order of about two percent.

Underwriting spreads. In addition to savings on reoffering yields to investors, the bond bank narrows the underwriting spread that bridges the gap to the real interest cost to the municipality.

Underwriting costs per thousand vary with size of issue, with rating, and number of bidders per issue, which itself is a function of issue size and rating. As computed by Kessel [1971, Tables 5 and 7], the difference in underwriting costs between an issue of $\$ 850,000$ (the mean size of a participating issue) and $\$ 46$ million (the size of the first Vermont Bond issue) is about $\$ 1$ per thousand. The difference in costs of under- 
writing an Aa and Baa (or unrated) bond is about $\$ 2.25$ per thousand. About $\$ 0.45$ of this difference results from the greater number of bidders the more highly rated bond attracts. These figures suggest that rating arbitrage has a greater impact on cost savings than economies of scale in underwriting. It should be noted that for privately placed issues, where there is by definition no underwriter, agent's fees are substantially lower but not enough to offset the higher reoffering yields.

Other flotation costs. The major flotation costs which can be pooled through the bond bank include: financial counsel; the printing of the notice, prospectus, and bond itself; and the rating. All of these are subject to economies of scale [MFOA, n.d.]. While not all towns would have utilized financial advisers, the calculations below assume they did.

Total cost savings. The total cost savings of the municipal bond bank is estimated by comparing the reoffering yields, underwriting spreads, and other flotation costs of the eight consolidated issues of the Vermont and Maine Municipal Bond Banks with eight hypothetical yields, spreads, and flotation costs of their components if issued separately. All cost estimates are based upon the assumptions described above, rather than upon the observed costs ex-post. The reason for this approach is that it provides a method of estimating the ex-ante advantage to a town of issuing through the bond bank or to a state of adopting a municipal bond bank.

The overwhelming impact of the Vermont and Maine Municipal Bond Banks has been the ratings arbitrage that has permitted savings in reoffering yields, and to a lesser extent, in underwriting costs. Only about one-quarter of the savings are due to economies of scale in underwriting and other flotation items (see Table 1).

The total cost savings of the bond banks have been on the order of two and one-half to five percent of the value of the bond issue. These cost savings can be enhanced by considering the lowered costs of calling and refunding municipal debt. The first Vermont issue was in fact refunded at a reoffering yield about one point lower than the yield of fourteen months earlier. Because in Vermont municipalities cannot issue callable bonds, all of this saving can be imputed to the bond bank. In states with no such restrictions, each town might have attempted to refund its debt separately in response to lower interest rates. This is unlikely, especially since in the absence of sophisticated financial advice, debt might have been placed privately without call provisions. At a minimum, these savings from use of the call provision equals the underwriting plus other flotation costs. Ex-ante the expected value of a munincipal bond bank should include the savings from the refunding operations times the probability of exercising the call provision.

It has been alleged that the transactions cost savings of the municipal bond bank is so great that municipalities with higher ratings than the bond bank might profit by issuing through it. In Vermont, in fact, Montpelier with an Aaa rating issued a debt of $\$ 400,000$ through the Vermont 
TABLE 1

Savings Due to the Maine and Vermont Municipal Bond Banks, 1970-1975 $(\$ 000 \mathrm{~s})$

\begin{tabular}{|c|c|c|c|c|c|c|c|c|c|c|c|}
\hline & \multirow{2}{*}{$\begin{array}{l}\text { Size of } \\
\text { Issue }\end{array}$} & \multirow[b]{2}{*}{ Interest } & \multicolumn{2}{|c|}{ Underwriting } & \multirow{2}{*}{$\begin{array}{l}\text { Fin. } \\
\text { Adv. }\end{array}$} & \multirow{2}{*}{$\begin{array}{l}\text { Bond } \\
\text { Notice }\end{array}$} & \multirow{2}{*}{$\begin{array}{l}\text { Bond } \\
\text { Prosp. }\end{array}$} & \multirow{2}{*}{$\begin{array}{l}\text { Bond } \\
\text { Print. }\end{array}$} & \multirow[b]{2}{*}{ Rate } & \multirow[b]{2}{*}{ Other } & \multirow[b]{2}{*}{ TOTAL } \\
\hline & & & Rating & Size & & & & & & & \\
\hline \multicolumn{12}{|l|}{ Maine } \\
\hline $8 / 8 / 73$ & $\$ 9,000$ & $259-268$ & 12 & 2 & 50 & 3 & 7 & 6 & 8 & 5 & $352-361$ \\
\hline $4 / 3 / 74$ & 11,000 & $145-146$ & 13 & 2 & 49 & 3 & 7 & 6 & 8 & 4 & $237-238$ \\
\hline $10 / 22 / 74$ & 9,000 & $261-267$ & 8 & 2 & 49 & 3 & 7 & 6 & 8 & 6 & $350-357$ \\
\hline $3 / 20 / 75$ & 12,000 & $308-311$ & 11 & 3 & 59 & 3 & 6 & 7 & 9 & 4 & $410-413$ \\
\hline TOTAL & $\$ 41,000$ & $973-993$ & 44 & 9 & 207 & 12 & 27 & 25 & 33 & 19 & $1,349-1,369$ \\
\hline \multicolumn{12}{|l|}{ Vermont } \\
\hline $1 / 11 / 71$ & $\$ 41,230$ & $1,250-1,289$ & 68 & 39 & 218 & 13 & 27 & 24 & 36 & 23 & $1,699-1,738$ \\
\hline $3 / 14 / 72 *$ & 18,205 & $567-585$ & 30 & 7 & 98 & 6 & 12 & 11 & 16 & 14 & $760-778$ \\
\hline $12 / 20 / 72$ & 6,930 & $196-201$ & 13 & 1 & 50 & 3 & 8 & 5 & 9 & 6 & $291-296$ \\
\hline $1 / 15 / 74$ & 10,380 & $680-729$ & 18 & 2 & 60 & 4 & 7 & 6 & 11 & 18 & $807-854$ \\
\hline TOTAL & $\$ 76,745$ & $\overline{2,693-2,804}$ & $\overline{128}$ & $\overline{49}$ & $\overline{426}$ & $\overline{26}$ & 54 & $\overline{47}$ & $\overline{71}$ & 63 & $\overline{3,557-3,668}$ \\
\hline
\end{tabular}

Source: Goldman, Sachs \& Co., Prospectus of the Maine Municipal Bond Bank, 1975 Series A, B, C, and D, 6 March 1975; Prospectus of the Vermont Municipal Bond Bank, 1972 Series $A$ and $B$

*Excludes refunding of previous issue. 
Bond Bank. The methodology here suggests that the savings were probably inconsequential. Montpelier probably saved about $\$ 5000$ in underwriting and other flotation costs, but ended up paying $\$ 5000$ more in discounted interest payments. Generally, the more highly rated towns would benefit from joining a bond bank for only extremely small issues.

The external costs of the bond bank cannot be ignored. The reserve fund of the bank operates on an effective federal subsidy of about two points. Since this insurance is necessary to maintain the rating of the bank at $\mathrm{Aa}$, the unsubsidized alternative for the municipalities would be private municipal bond insurance at roughly one and one-half percent of the issue, or mutual insurance at roughly one-half percent as provided by Minnesota [Forbes and Renshaw, 1972]. If the subsidized reserve fund were substituted with either form of bond insurance, then the savings of the municipal bond bank would decrease substantially.

\section{TWO CONNECTICUT INNOVATIONS}

\section{Umbrella Bonds}

Just as small towns have difficulty financing their capital expenditures, small unrated companies have difficulty in financing plant and equipment. Generally restricted by their size to local capital markets, small companies tend to face a lending oligopoly. To some extent insurance companies add flexibility to markets through private placements; however, the risk premiums and transactions costs are substantial [Shapiro and Wolf, 1972].

As a means of increasing the access of small companies to national capital markets, Connecticut has created the "Umbrella Bond"' which is in essence an industrial revenue bond bank. Like a general obligation bond bank, the umbrella program lends directly to companies who are seeking credits of $\$ 1$ million or less to finance land, plant, machinery, and pollution control equipment. The umbrella program in turn issues a consolidated bond* with four levels of security behind it: the real properties themselves, the reserve fund of the umbrella program, the mortgage insurance program of the Connecticut Development Authority (CDA), and a general obligation of the state to replenish the reserve fund.

The first and third levels of security distinguish the umbrella bond bank from the general obligation counterpart. First, while the general obligation bank provides 100 percent financing of local capital expenditures, the umbrella bond program finances only 80 to 90 percent like a conventional mortgage lender. The 10 to 20 percent equity requirement reduces the DCA's risks. in case of default or bankruptcy. Second, while the general obligation bank lends to towns at the same rate as it can borrow itself, the umbrella program lends at up to one and one-half per-

\footnotetext{
*To overcome the \$1-5 million Internal Revenue Service restriction on the size of industrial revenue issues, the consolidated bond is issued in series of up to $\$ 1$ million each.
} 
cent higher than its borrowing cost. This differential is collected as an insurance premium in the state's mortgage guarantee program. In addition, companies are charged a one-half percent of the value of the loan as a one-and-for-all fee.

The umbrella bond program has clearly tapped a different market from the traditional "self-sustaining" revenue bond programs. As indicated by Dun and Bradstreet's indices of "financial strength"" and "composite credit assessment," the umbrella program encompasses a far higher proportion of companies which are not included in the Reference Guide or which are included but not rated. Of the companies whose financial strength is reported, there is a disproportion of smaller ones participating in the umbrella program (see Tables $2 \mathrm{a}$ and $2 \mathrm{~b}$ ). Of these companies, however, there are not many differences in the distribution of ratings. Finally, the average size of debt under the umbrella program is only $\$ 380,000$, compared to $\$ 3,950,000$ under the self-sustaining program (see Table 2c).

It is much more difficult to determine the ex-ante cost savings generated by an umbrella revenue bonding than by municipal bond banking. The main difficulty lies in specifying the alternative credit channels of the companies participating in the umbrella program. Very few of these companies, by virtue of their lack of rating, could have issued industrial revenue bonds on public markets or even through private placements. Others might have sought medium-term loans from commercial banks, while others might have been unable to borrow at all.

As a conservative estimate, it is assumed that the alternatives would have been publicly-floated or privately-placed industrial revenue bonds. While the interest rate on these bonds cannot be specified, the underwriting and other flotation costs can be. As estimated in Table 3, these cost savings alone amount to three percent of the value of the debt issue.

The program had been financed until mid-December 1975 on the basis of bond anticipation notes. Therefore it is difficult to determine as yet how the market evaluates these umbrella bonds.

From the state's point of view, an evaluation of the program over the long-run simply hinges upon whether the insurance premiums are sufficient to offset the losses from default and bankruptcy. Beyond this, there is little reason to believe that there are any external benefits from the financing of small-business capital expenditures. From the national point of view, both umbrella and self-sustaining revenue bond programs undervalue the cost of capital by virtue of the taxation on interest foregone by the U.S. Treasury.

\section{Product Development Corporation}

New product development is an important rnode of expansion of existing enterprises and the creation of new enterprises. On the macroeconomic level, new product development is the major vehicle for tech- 


\section{TABLE 2a}

Percentage Distribution of Estimated Financial Strengths of Companies Using CDA Umbrella and Self-Sustaining Revenue Bonds, FYs 1973 \& 1974

\begin{tabular}{|c|c|c|c|c|c|c|c|c|c|c|c|c|c|c|}
\hline Program & $\begin{array}{l}\text { Not } \\
\text { Shown } \\
\text { in Guide }\end{array}$ & $\begin{array}{l}\text { Size Not } \\
\text { Indicated } \\
\text { in Guide }\end{array}$ & $5 \mathrm{~A}$ & $4 \mathrm{~A}$ & $3 \mathrm{~A}$ & $2 \mathrm{~A}$ & $1 \mathrm{~A}$ & $\mathrm{BA}$ & $\mathrm{BB}$ & $\mathrm{CB}$ & $\mathrm{CC}$ & DC & DD & EE \\
\hline UBs & 32.0 & 41.0 & 0 & 0 & 3.8 & 1.3 & 3.8 & 6.4 & 2.6 & 3.8 & 1.3 & 2.6 & 1.3 & 1.3 \\
\hline SSRBs & 33.9 & 26.8 & 19.6 & 3.6 & 7.1 & 0 & 3.6 & 5.4 & 0 & 0 & 0 & 0 & 0 & 0 \\
\hline
\end{tabular}

\begin{tabular}{|c|c|c|c|c|c|c|}
\hline & & & & Degrees of Freedom & $\mathrm{X}^{2}-$ Value & Critical Value \\
\hline Note A: & (i) including & $\left\{\begin{array}{l}\text { not } \text { rated } \\
\text { not shown }\end{array}\right\}$ & categories & 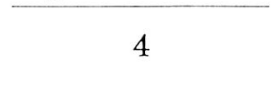 & 22.50 & 13.28 at .01 level \\
\hline . & (ii) excluding & $\left\{\begin{array}{l}\text { not rated } \\
\text { not shown }\end{array}\right\}$ & categories & 2 & 18.85 & 9.21 at .01 level \\
\hline
\end{tabular}

Note B: Estimated Financial Strengths in $\$ 000$ s Sales

\begin{tabular}{|c|c|c|c|}
\hline $5 \mathrm{~A}$ & Over $\$ 50,000$ & $\mathrm{BB}$ & $200-299$ \\
\hline $4 \mathrm{~A}$ & $10,000-49,000$ & $\mathrm{CB}$ & 125-199 \\
\hline $3 \mathrm{~A}$ & $1,000-9,999$ & $\mathrm{CC}$ & $75-124$ \\
\hline $2 \mathrm{~A}$ & 750-999 & $\mathrm{DC}$ & $50-74$ \\
\hline $1 \mathrm{~A}$ & $500-749$ & DD & $35-49$ \\
\hline $\mathrm{BA}$ & $300-499$ & $\mathrm{EE}$ & $20-34$ \\
\hline
\end{tabular}

Source: Dun and Bradstreet, Reference Guide, 1975. 
TABLE 2b

Percentage Distribution of Composite Credit Appraisals for Companies Using CDA Umbrella and Self-Sustaining Revenue Bonds, FYs 1973 \& 1974

\begin{tabular}{|c|c|c|c|c|c|c|c|c|}
\hline Program & & $\begin{array}{c}\text { Not } \\
\text { Shown } \\
\text { in Guide }\end{array}$ & $\begin{array}{l}\text { Rating Not } \\
\text { Indicated } \\
\text { in Guide }\end{array}$ & $\begin{array}{c}\text { Highest } \\
1\end{array}$ & 2 & 3 & $\begin{array}{c}\text { Lowest } \\
4\end{array}$ & \\
\hline UBs & & 32.0 & 34.6 & 12.8 & 10.3 & 11.5 & 0 & \\
\hline \multirow[t]{2}{*}{ SSRBs } & & 37.5 & 25.0 & 21.4 & 5.4 & 10.7 & 0 & \\
\hline & & & & & & Freedom & $\mathrm{x}^{2}-$ Value & Critical Value \\
\hline \multirow[t]{2}{*}{ Note C: } & (i) & including & $\left\{\begin{array}{l}\text { not rated } \\
\text { not shown }\end{array}\right.$ & $\{$ groups & & & 28.5 & 13.28 at .01 \\
\hline & (ii) & excluding & $\left\{\begin{array}{l}\text { not rated } \\
\text { not shown }\end{array}\right.$ & groups & & & 2.34 & 9.21 at .05 \\
\hline
\end{tabular}

TABLE $2 \mathrm{c}$

Percentage Distribution of Ioan and Issue Sizes,

CDA Umbrella and Self-Sustaining Revenue Bonds, FYs 1973 \& 1974

Size $(\$ 000 \mathrm{~s})$

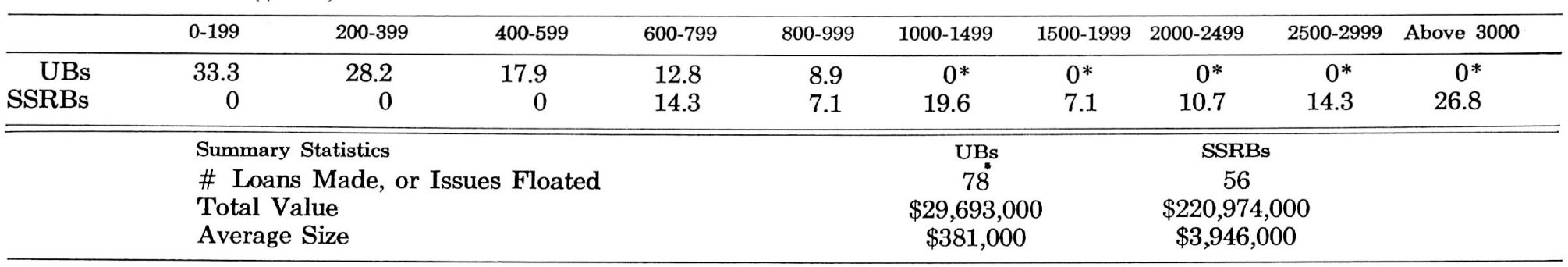

Source: Connecticut Development Authority, Annual Report, Fiscal Years 1973 and 1974

*Constrained to zero by IRS regulation. 
TABLE 3

Savings Due to Umbrella Bonding:

Publicly-Offered SSRBs as Alternative Finance,

But Excluding Interest Differentials

\begin{tabular}{|c|c|c|c|c|c|c|}
\hline & \multirow[b]{2}{*}{$\begin{array}{c}\text { Loan Size } \\
(\$ 000 s)\end{array}$} & \multicolumn{2}{|c|}{ Costs $/ \$ 1000$ Issued } & \multirow[b]{2}{*}{$\underset{(\$)}{\text { Total }}$} & \multirow{2}{*}{$\begin{array}{l}\text { Size of } \\
\text { Issue } \\
(\$ 000 s)\end{array}$} & \multirow[b]{2}{*}{$\begin{array}{c}\text { Total Cost } \\
(\$ 000 \mathrm{~s})\end{array}$} \\
\hline & & $\begin{array}{c}\text { Flotation } \\
\text { Costs* }\end{array}$ & $\begin{array}{c}\text { Underwriting } \\
\text { Costs** }\end{array}$ & & & \\
\hline Costs to & a) $0-2997$ & $10.69-13.90$ & 75.30 & $85.99-89.20$ & $\$ 11,756$ & $\$ 1,011$ to \\
\hline Individual & b) $300-499\}$ & & & & & $\$ 1,047$ \\
\hline Companies & c) $500-999$ & $12.03-12.87$ & 75.30 & 87.33-88.17 & $\$ 8,062$ & $\begin{array}{l}\$ 704 \text { to } \\
\$ 711\end{array}$ \\
\hline Total & d) $=a+b+c$ & & & & $\$ 19,817$ & $\begin{array}{l}\$ 1,715 \text { to } \\
\$ 1,758\end{array}$ \\
\hline \multirow[t]{2}{*}{ SAVINGS } & $\begin{aligned}e)= & \text { Costs } \\
& \text { to CDA }\end{aligned}$ & & & 47.09 & $\$ 23,635^{* * *}$ & $\$ 1,113 * * *$ \\
\hline & f) $=d-e$ & & & & & $\begin{array}{l}\$ 602 \text { to } \\
\$ 645\end{array}$ \\
\hline
\end{tabular}

Sources: $\quad *$ MFOA Survey, Costs Involved in Marketing State/Local Bonds (Chicago: n.d.).

**Shapiro and Wolf, The Role of Private Placements in Corporate Finance (Boston: Harvard Business School, 1972). ***Connecticut Development Authority, Draft Prospectus (1975).

Note: $\quad$ Difference between (d) and (e) in size of issue reflects $\$ 2,705,000$ Capital Reserve Fund 
nological change. The development of new products is an inherently risky investment, as little is known about the underlying engineering feasibility and still less about the costs of production and eventual market demand. In this context, the Connecticut Product Corporation is operating in a range of risk that is usually shunned by even the most daring venture capitalists.

Although New England is a highly-touted center of venture capitalism, there is little external private financing available for product development currently. Several factors have lead to the decline in the supply of funds for this activity. First, with the increasing complexity of science and technology, the independent genius working in his attic is giving way to the corporate research department as a generator of inventions. Second, there has been a decline in the volume of federal cost-plus defense contracts, and a shift away from unsolicited proposals. There is some likelihood that the new Energy Research and Development Agency will reverse these trends. Third, both federal and state governments are pushing the earned and unearned income tax rates closer to each other, thereby reducing the returns to risk taking. Fourth, the decline of the stock market and the concomitant collapse of the new issues market have caused venture capital companies to remain "locked in" to old investments and to be unwilling to invest their remaining liquidity in equities. While in the past a few venture capital companies financed new product development (most generally financed businesses that have already developed their new products), almost all have moved into safer areas. If and when the stock market recovers, venture capitalists may be less willing to take such risks as in the past.

With a few exceptions, states have ignored product development as a mode of economic development promotion. New York and Pennsylvania have had "science and technology foundations" with the avowed purpose of providing grants for pure and applied research, with the vague promise that somehow the fruits will be reaped as state economic development. Even if such research ultimately generated a marketable product, there is no guarantee that it would be produced in those states nor is there any mechanism by which the grant expenditures could be recaptured directly. The Massachusetts Science and Technology Foundation (MSTF) operates in an area much further from applied research and closer to commercial application. Mainly through a "technology exchange," this Foundation attempts to broker between entrepreneurs and inventors but provides no funding directly. Even closer to the commercial application side is the New England Industrial Resource Development program (NEIRD), which is funded by the Economic Development Administration and the New England Regional Commission, the Title V agency. Like MSTF, this program maintains files of inventors and entrepreneurs whom they attempt to match. In contrast to MSTF, the program provides technical assistance to inventors regarding patent procedures, the preparation of business plans, and market research. 
The boldest state experiment has been patterned after the National Research Development Corporation (NRDC), which was founded in Britain in 1948. Initally organized to capitalize on the commercial possibilities of inventions financed by the government during World War II, NRDC provides direct grants to inventors to bring their ideas to commercial fruition. NRDC proposed to capture the returns on these investments by taking an equity position in the resulting businesses or accepting royalties on sales. It should be noted that NRDC has financed new products in new businesses and has financed applied research as well as pure product development. While a cost-benefit analysis of this entity has not been performed, there is some evidence that NRDC has failed to break even on its balance sheet. Funded by Treasury loans, NRDC has continued to receive a forgiveness on interest, ostensibly because of the external economics of scientific research.

Unlike the NRDC, the Connecticut Product Development Corporation does not take an equity position, only royalties on sales; and finances inventors in joint partnership with established businesses who hope to market the product. These distinctions are important. "The fact that CPDC engages in product development rather than applied research suggests that the generation of "public goods" or "external economies" of knowledge are less; therefore, its performance should be internalized on its own balance sheet. The fact that it finances individuals who already have backing from existing businesses provides a private-market screen from commercially unviable ideas, reduces the financial risks of the $\mathrm{CPDC}$, and separates the technological risks of new product development from the entrepreneurial risks of new business development.

Originally established in 1972, CPDC was authorized to issue $\$ 10$ million in general obligation bonds. Not until August 1974 was the constitutionality of this act upheld by the State Supreme Court. Surviving a change in government in January 1975, CPDC received its first state financing in May. To date CPDC has invested in five projects at an expenditure of less than $\$ 1$ million. Although some of these projects hold forth the prospect of early returns, it is premature to judge whether or not CPDC will be able to achieve its goals.

Without question, CPDC seems like a worthwhile experiment. Indeed, it has received funding from the Federal Bureau of Standards under its Experimental Technology Incentives Program (ETIP). Since the public goòd or external economies argument does not seem particularly strong in this case, we would argue that the criterion of success should be whether or not CPDC earns returns higher than the social opportunity cost of capital, which is higher than the tax-exempt cost of funds to Connecticut.

\section{CONCLUSION}

The three capital market innovations described here are promising experiments that are considerably different from those undertaken by 
states previously. First, they impose considerable financial risk upon the states. Second, they are considerably more market-disciplined than other promotional schemes, i.e., they permit market evaluation of demand for program outputs as well as market criteria of success. Since they depend upon funds raised by the flotation of debt rather than by legislative appropriation, they can be established as public-purpose corporations that can expand as demand dictates. To the extent that they earn profits, such expansion is socially desirable. To the extent that they operate at a loss, these corporations will go out of business. This can be said for few government programs that fail.

From the regional perspective, the municipal bond bank and umbrella bond program seem most opportune for "peripheral" areas with poorly developed capital markets. The product development corporation concept seems most applicable to states in the "center," with skilled labor force, well-developed capital markets, highly diversified suppliers, and plentiful technical/legal consultants. States on the periphery are less likely to serve as successful incubators. Without attempting to make invidious distinctions, it would appear to a Yankee outsider that a product development corporation would function more successfully in the Research Triangle of North Carolina, near the aerospace complex in Houston, or in Oak Ridge, than in the Florida panhandle or West Virginia.

To the extent that these programs remain solvent and diffuse nationally, they contribute to national welfare. As regional development programs, they are somewhat limited in their impact. The municipal bond bank, for example, seems to lower the cost of municipal infrastructure by about two-and-a-half to five percent. These savings can hardly have a decisive impact on regional growth. A four percent savings in infrastructure costs may translate into a four percent increase in taxes net of benefits from public services. Since taxes are such a small share of doing business [Due, 1961], the impact of the bond bank on the returns to sales and returns on capital would seem infinitesimal. Consequently, the municipal bond bank is a blunt economic development instrument.

Similarly, while an umbrella revenue bond program may lower the cost of plant and equipment for small businesses, its regional impact may be relatively small. As Stober and Falk [1969] have shown, a two point variation in costs of capital is swamped by five or ten percent variations in costs of labor which are not uncommon.

The product development corporation is the biggest unknown because there is little experience to compare it with. Consequently, the Connecticut experiment merits careful attention and evaluation.

\section{Why should loopholes be expanded to finance private businesses?}

A major criticism levied against the types of instruments described here is that they depend upon Federal subsidies, which result from the use of tax-exempt revenue bonds, and that they provide "unwarranted" subsidies to private business. It should be roted that the attractiveness 
of these instruments extends far beyond their ability to attract funds at the tax-exempt interest rate. They are first and foremost transactionscost and risk reducing mechanisms, for which the tax-exempt feature is only incidental. While they in fact will probably lead to the expansion in the issue of tax--exempt instruments, Federal legislation to eliminate the tax-exemption on interest of municipals will probably not lead to the demise of these particular instruments.

If these mechanisms do not depend upon subsidies, why have they not been developed by the private sector?

This question assumes that the private capital market is perfect or automatically perfectable. While the improvements in the nation capital markets have been impressive, especially since 1900 [Goldsmith, 1968], many of these improvements resulted from Federal "seeding." The creation of a farm credit system and long-term home mortgages was a result of Federal initiative. Once it became clear that the risks of farm and home loans were less than originally believed, these financing systems eventually became privatized. Modern day examples are the creation of private bond insurance, industrial lease insurance, and private umbrella bond schemes after their viability had been demonstrated by the states.

Do regional differences in capital costs have a significant impact on industrial location?

The reduction in regional capital costs as a result of the mechanisms described above are unlikely to have a major impact on industrial location. As Stober and Falk [1969] have shown, a two point decrease in capital costs is likely to be swamped by a five percent difference in labor costs among regions. Industrial relocation, however, may be largely a non-issue since much of the differential growth in employment among states is due to differential rates of births, deaths, expansions, and contractions rather than by migration of jobs. Perhaps a more germane question is: how much income and jobs are created by the increased profits which the reduced capital costs generate? While on a national basis about 50 percent of all profits are reinvested, this ratio may not hold in any particular state. Reinvestment rates are likely to be the highest for small, single-plant firms with resident owners. Conversely, reinvestment rates are probably lowest for multi-plant firms with geographically dispersed stockholders. To the extent that the mechanisms described above are especially helpful to the former type of firm, the reinvestment benefits can be substantial. Such speculation suggests a fruitful area for research on capital markets. 


\section{BIBLIOGRAPHY}

Due, John. "Studies of State-Local Tax Influences on Location of Industry," National Tax Journal, 14 (1961), 163-173.

Forbes, Ronald and Renshaw, Edward. "State Bond Banks." Municipal Finance Officers Association, Special Bulletin 1972E, 1 September 1972 .

Gishlick, Herbert. "Plant Location in Manufacturing: A Testing of some Hypotheses." Unpublished Ph.D. dissertation, University of Pennsylvania, 1974.

Goldsmith, Raymond. Financial Intermediaries in the American Economy Since 1900. New York: National Bureau of Economic Research, 1968.

Hirschman, Albert O. The Strategy of Economic Development. New Haven: Yale University Press, 1958.

Katzman, Martin T. and Daniels, Belden H. "Development Incentives to Induce Efficiencies in Capital Markets." Report prepared for the New England Regional Commission, 1975.
Kessel, Fieuben. "A Study of the Effects of Competition in the Tax-Exempt Bond Market," olournal of Political Economy, 79 (July/August 1971), 706-738.

Municipal Finance Officers Association, "Survey: Subject - Costs Involved in Marketing State/Local Bonds." MFOA, (n.d.).

New England Regional Commission, "Governors Task Force on Capital and Labor Markets," final report, November 1975.

Petersen, John E. "Background Paper." The Rating Game. New York: Twentieth Century Fund, 1974.

Phelps, Charlotte. "The Impact of Tightening Credit on Municipal Capital Expenditures in the United States," Yale Economic Essays, 1 (Fall 1961), 275-321.

Shapiro, ]Eli and Wolf, Charles. The Role of Private Placements in Corporate Finance. Boston: Harvard Business School, 1972.

Stober, William J. and Falk, Lawrence $\mathrm{H}$. "The E:fect of Financial Inducements on the Location of Firms," Southern Economic Journal, 36 (July 1969), 25-35. 